\title{
The Efficacy and Safety of Ertapenem Therapy in Children with Urinary Tract Infections due to ESBL-Producing Microorganisms
}

\author{
Esra Çelik Kuzaytepe, ${ }^{1}$ Ayşe Karaaslan,, Yasemin Akın,, Nuran Küçük, \\ Özge Karataş, ${ }^{1}$ Demet Hacıseyitoğlu, ${ }^{2}$ Serap Genç Yüzüak, ${ }^{1}$ Melis Şirinoğlu'
}

\footnotetext{
'Department of Pediatrics, Kartal Dr. Lütfi Kırdar Training and Research Hospital, İstanbul, Turkey

${ }^{2}$ Department of Clinical Microbiology Laboratory, Kartal Dr. Lütfi Kırdar Training and Research Hospital, İstanbul, Turkey

Submitted: 30.06.2016 Accepted: 28.07.2016

Correspondence: Yasemin Akın, Dr. Lütfi Kırdar Kartal Eğit. ve Araşt.

Hastanesi, Çocuk Sağlığı ve Hast. Kliniği, Kartal, İstanbul, Turkey E-mail: gulcin.ggo@gmail.com

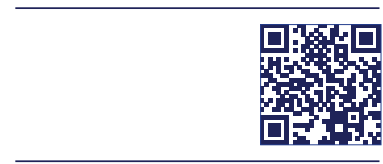

Keywords: Children; ertapenem; ESBL; urinary tract infection.
}

\begin{abstract}
Objective: In this study, we evaluated the clinical efficacy and safety of ertapenem treatment for urinary tract infections (UTIs) in children.

Methods: In this retrospective study, we analyzed the records of 22 patients, aged 5 months to 153 months, who received ertapenem therapy for UTI caused by extended spectrum beta-lactamase (ESBL)-producing microorganisms between August 2015 and June 2016.

Results: Sixteen (72.7\%) female and 6 (27.2\%) male children with a mean age of $53.0 \pm 43.6$ months (range: 5 to 153 months) were enrolled in the study. Escherichia coli $(n=21)$, and Klebsiella pneumoniae $(n=I)$ were identified in the urine cultures of these 22 patients. Treatment duration was 10 days for all patients. No adverse drug-related effects were seen.
\end{abstract}

Conclusion: Ertapenem can be used safely to treat UTI in children caused by ESBL-producing microorganisms.

\section{INTRODUCTION}

Urinary tract infection (UTI) is one of the frequently seen clinical problems of pediatric age group. In a study performed by Söylemezoğlu et al., UTI was detected in $3 \%$ to $5 \%$ of female children, and $1 \%$ of male children. ${ }^{[1]}$ UTIs are classified as acute pyelonephritis/upper urinary system infection or cystitis/lower urinary tract infection. In populations with lower antimicrobial resistance, UTI in children older than 3 months of age can be treated with oral an- tibiotics; cephalosporins such as co-amoxilav are typically used for 7 days. ${ }^{[2]}$ In cases where oral antibiotherapy is not feasible (e.g., oral intake is not tolerated, worse clinical picture, lethargy, immunosuppression), then patients are hospitalized and intravenous (IV) cephalosporin (cephtriaxone) may be used.

Parenteral antibiotherapy can be used two and four days, and if clinical status of the patient improves, then treatment can be maintained with oral antibiotherapy. ${ }^{[2]}$ UTIs that develop due to extended spectrum beta-lactamase 
(ESBL)-producing microorganisms are now globally seen in gradually increasing numbers and cause treatment difficulties. Prevalence of nosocomial or community-acquired infections caused by ESBL-producing microorganisms is growing. Many studies have reported prevalence that varies between $20 \%$ and $54 \% .{ }^{[3,4]}$ Kizilca et al. ${ }^{[5]}$ found rates of ESBL production by Escherichia coli (E. coli) and Klebsiella species in community-acquired UTIs at $41 \%$ and $53 \%$, respectively. In a similar study conducted by Conkar et al., rates of ESBL production by $\mathrm{E}$. coli and Klebsiella species in community-acquired UTls were detected at $46 \%$ and $40 \%$, respectively. ${ }^{[6]}$

Carbapenems such as ertapenem, imipenem, meropenem, and doripenem are the most effective antibiotics to treat infections caused by ESBL-producing microorganisms. Ertapenem is the latest addition to this group, and it has a narrower spectrum than the others. Ertapenem is more effective on intra-abdominal infections caused by Enterobacteriaceae species and anaerobes; however, it is less effective against Pseudomonas aeruginosa, Acinetobacter, and Gram-positive bacteria compared to other carbapenem antibiotics. ${ }^{[7]}$ Although this antibiotic has a narrow spectrum, rational antibiotic use has decreased the rate of development of drug resistance.

Because of its long half-life, single daily dosage is one of the important advantages that facilitate its use. Ertapenem has been licensed both in the United States and Europe since the beginning of the 2000 s. It has been recommended for use in children older than 3 months of age for the treatment of intra-abdominal infections, UTIs, complicated skin and soft tissue infections, community-acquired pneumonias, and acute pelvic infections since 2005. ${ }^{[8]}$ Therefore, few studies exist demonstrating the effectiveness of ertapenem therapy.

The aim of the present study was to investigate clinical effectiveness and reliability of ertapenem in 22 children with UTI.

\section{MATERIAL AND METHODS}

Twenty-two patients aged between 5 months and 153 months who were hospitalized with indication of UTI caused by ESBL-producing microorganisms and who received ertapenem treatment between August 2015 and June 2016 were included in the study.

In this retrospective review, patient demographic information (age and gender), laboratory and radiological characteristics of the cases, underlying diseases, and clinical features of disease were retrieved from medical files of the patients. Ertapenem treatment was started after approval from the department of children's health and diseases.

Diagnosis of complicated UTI was made based on the following criteria: I) pyuria (white blood count $>5 \mathrm{hpf}$ in centrifuged urine sample); 2) nitrate or leukocyte esterase positivity in urine samples; 3 ) detection of pathogenic microorganisms in cultures of a) mid-stream urine sample ( $\geq 105 \mathrm{cfu} / \mathrm{mL}$ ), b) catheterized urine sample ( $\geq 104 \mathrm{cfu} /$ $\mathrm{mL}$ ), c) urine sample collected using suprapubic catheter ( $>0 \mathrm{cfu} / \mathrm{mL}$ ); 4)presence of at least 2 of the following UTI symptoms: fever, suprapubic, dysuria, urinary frequency or urgency, or hypothermia. ${ }^{[9]}$ Cases that did not meet these criteria were not included in the study.

Identification of the microorganisms and analysis of ESBL were performed using Vitek 2 automated microbial identification system (bioMerieux, Marcy l'Etoile, France), and evaluations were made based on guidelines of the Clinical and Laboratory Standards Institute. ${ }^{[10]}$

Empirical treatment was applied for all patients hospitalized with diagnosis of UTI. Based on antibiogram results of initial and urine culture and follow-up taken on third day of treatment, antibiotherapy was adjusted accordingly. Patients with UTI caused by ESBL-producing microorganisms and treated with ertapenem were included in the study. Patients received ertapenem IV dose of $30 \mathrm{mg} / \mathrm{kg}$ bid. All patients underwent urinary ultrasonographic examinations.

\section{RESULTS}

Study population consisted of 16 (72.7\%) female, and $6(27.2 \%)$ male children with an overall mean age of 53.0 \pm 43.6 months (range: 5-153 months; median 43 months). Four of 9 cases had neurogenic bladder secondary to spina bifida, while other cases had concomitant diseases including vesicoureteral reflux $(n=2)$, malnutrition $(n=I)$, phimosis $(n=I)$ (following treatment of UTI, patient underwent circumcision operation), and congenital toxoplasmosis (Table I).

Twenty-two cases underwent urinary system ultrasonographic examination. In 3 cases with neurogenic bladder secondary to spina bifida, extrarenal pelvis and grade I pelviectasis $(n=I)$; ureteral duplication and grade 3 vesicoureteral reflux $(n=l)$, and bilateral grade 4 vesicoureteral reflux $(n=1)$ were detected. One patient with vesicoureteral reflux also had left atrophic kidney.

E. coli $(n=2 I)$ and Klebsiella pneumonia were detected on urine culture media. On third day of treatment bacterial growth was not detected in any of follow-up urine cultures. After 48 hours of ertapenem treatment, elimination of signs of infection was accepted as clinical treatment response. Clinical success was achieved in all cases. None of the blood cultures performed concomitantly with urine cultures revealed bacterial growth. Duration of treatment was extended to 10 days in all cases. No treatment-related side effects were seen. 


\section{DISCUSSION}

Since community-acquired ESBL-producing microorganisms were defined nearly 20 years ago, the incidence of UTI caused by community-acquired and nosocomial ESBLproducing E. coli and other Gram-negative bacteria has increased worldwide. ${ }^{[1-14]}$ Degnan et al. detected 7.8\% incidence of ESBL-producing microorganisms in UTIs in their investigation of 370 children. ${ }^{[15]}$ This condition causes treatment difficulties. ESBL-producing microorganisms are resistant to beta-lactam antibiotics, penicillins, cephalosporins, and aztreonam. Aminoglycosides can be used after results of antibiotic susceptibility tests are obtained; however, due to risk of antibacterial resistance, their use is limited. Han et al. used aminoglycosides to treat UTIs in children caused by ESBL-producing microorganisms with successful results. ${ }^{[16]}$ Recently, carbapenems such as meropenem, imipenem, and doripenem have most frequently been used against ESBL-producing microorganisms. However, a limited number of studies have been performed on this subject. Ertapenem is preferred over other carbapenems due to its lower treatment cost, single dose, and ambulatory treatment advantages. In addition, it decreases potential carbapenem resistance of Acinetobacter and Pseudomonas aeroginosa. In the present study, the most important reason ertapenem was chosen for treatment of UTIs caused by ESBL-producing bacteria was the growing rate of bacterial resistance to carbapenems.

Duration of treatment of UTI is generally 7-10 days. In the presence of an underlying disease, longer treatment period is recommended. Prolonged treatment period has limitations, in that it is associated with increased treatment costs, longer hospital stay, and also increased risk of nosocomial infection. Because of its single IV or intramuscular dose schedule, use of ertapenem may be preferred since risks of longer treatment periods are decreased. In the present study, ertapenem treatment was used in consideration of these features of the drug, and duration of treatment was 10 days. Since favorable treatment responses were achieved, prolonged treatment of our patients was not required.

The youngest patient in the current study was 5 months old. Limited data are available about ertapenem use in children. Effectiveness and reliability in children aged between 3 months and 17 years information is based on controlled studies performed in adults, pediatric pharmacokinetic information, and comparative and controlled studies performed in children. ${ }^{[1,17]}$ Ertapenem therapy has now been used safely in children older than 3 months. The authors of this study also prefer to use ertapenem in the treatment of UTI caused by ESBL-producing microorganisms, excluding Acinetobacter and Pseudomonas aeroginosa.
Underlying urinary system anomaly increases the risk of development of UTI. ${ }^{[18]}$ In studies, vesicoureteral reflux has been the most frequently seen urinary system anomaly, and the most frequently encountered predisposing factor for UTI. ${ }^{[19,20]}$ In the present study, among diseases predisposing to UTI, we most frequently detected neurogenic bladder secondary to spina bifida.

Ertapenem is primarily metabolized by the kidneys. Therefore its concentration in urine is quite high. A study by Teppler et al. found that elevated liver transaminases (8.8\%), thrombophlebitis (4.5\%), nausea (2.5\%), and seizures $(0.2 \%)$ were side effects of ertapenem. ${ }^{[2]}$ During treatment period, we closely observed our patients for adverse clinical effects or laboratory test abnormalities; no side effects of the drug were observed.

During the treatment of UTIs, follow-up urine culture is no longer recommended; ${ }^{[20]}$ however, we still continue to obtain another urine culture in our clinic. Bacterial growth was not detected on any urine cultures obtained on third day of treatment in the present study, demonstrating the effectiveness of the ertapenem treatment.

Karaaslan et al. also determined ertapenem was effective and reliable for treatment of UTI caused by ESBLproducing microorganisms in a study of 77 children, results that are in agreement with present study findings. ${ }^{[2]}$

The present study confirmed the effectiveness and reliability of ertapenem in the treatment of pediatric UTI caused by ESBL-producing microorganisms.

\section{REFERENCES}

1. Söylemezoğlu O. Urinary tract infections. In: Hasanoğlu E, Düşünsel R, Bideci A, editors. Basic pediatrics. Ankara: Güneş Tip Kitapevleri; 2010. p. 929-35.

2. National Institute for Health and Clinical Excellence: Guidance. Urinary Tract Infection in Children: Diagnosis, Treatment and Longterm Management. London: RCOG Press; 2007.

3. Çelebi S, Yüce N, Çakır D, Hacımustafaoğlu M, Özkaya G. Risk Factors for and Clinical Outcomes of Infections Caused by ExtendedSpectrum- $\beta$-Lactamase-Producing Escherichia coli in Children: Results of a 5 Year Study. J Pediatr Inf 2009;3:5-10.

4. Demir N, Gençer S, Özer S, Doğan M. Genişlemişs spektrumlu $\beta$-laktamaz üreten gram negatif bakteri infeksiyonları için çeşitli risk fakörlerinin araştırılması. Flora 2008:13;179-88.

5. Kizilca O, Siraneci R, Yilmaz A, Hatipoglu N, Ozturk E, Kiyak A, et al. Risk factors for community-acquired urinary tract infection caused by ESBL-producing bacteria in children. Pediatr Int 2012;54:85862.

6. Conkar S, Demirkaya S. Distribution of community-acquired gram negative microorganisms detected in urine samples of pediatric patients and antibiotic resistance patterns at 2013. Dicle Medical Journal 2015;42:181-5.

7. UpToDate Database. http://www.uptodate.com/contents/combination-beta-lactamase-inhibitorscarbapenemsandmonobactams?source 
$=$ machineLearning $\&$ search $=$ ertapenem $\&$ selected Title $=5 \sim 36 \&$ secti onRank=18anchor $=\mathrm{H} 3$ \#H3.

8. Keating GM, Perry CM. Ertapenem: a review of its use in the treatment of bacterial infections. Drugs 2005;65:2151-78.

9. Elder JS. Urinary tract infections. In: Kliegman RM, Behrman R, Jenson H, Stanton B, editors. Nelson textbook of pediatrics. Philadelphia, Pa, USA: Saunders Elsevier; 2007. p. 2223-8.

10. CLSI. Performance standards for antimicrobial susceptibility testing; 25th Informational Supplement. CLSI Document M100-S25. Wayne, PA: Clinical and Laboratory Standards Institute; 2015.

11. Zilberberg MD, Shorr AF. Secular trends in gram-negative resistance among urinary tract infection hospitalizations in the United States, 2000-2009. Infect Control Hosp Epidemiol 2013;34:940-6.

12. Paterson DL, Bonomo RA. Extended-spectrum beta-lactamases: a clinical update. Clin Microbiol Rev 2005;18:657-86.

13. Ben-Ami R, Rodríguez-Baño J, Arslan H, Pitout JD, Quentin C, Calbo ES, et al. A multinational survey of risk factors for infection with extended-spectrum beta-lactamase-producing enterobacteriaceae in nonhospitalized patients. Clin Infect Dis 2009;49:682-90.

14. Dalgic N, Sancar M, Bayraktar B, Dincer E, Pelit S. Ertapenem for the treatment of urinary tract infections caused by extended-spectrum $\beta$-lactamase-producing bacteria in children. Scand J Infect Dis 2011;43:339-43.

15. Degnan LA, Milstone AM, Diener-West M, Lee CK. Extended-spectrum beta-lactamase bacteria from urine isolates in children.J Pediatr Pharmacol Ther 2015;20:373-7.
16. Han SB, Lee SC, Lee SY, Dae CJ, Kang JH. Aminoglycoside therapy for childhood urinary tract infection due to extended-spectrum $\beta$-lactamase-producing Escherichia coli or Klebsiella pneumoniae. BMC Infectious Diseases 2015;15:414.

17. Parakh A, Krishnamurthy S, Bhattacharya M. Ertapenem. Kathmandu Univ Med J (KUMJ) 2009;7:454-60.

18. Freedman AL. Urinary tract infections in children. In: Litwin MS, Saigal CS, editors. Urologic Diseases in America. U.S. Department of Health and Human Services, Public Health Service, National Institutes of Health, National Institute of Diabetes and Digestive and Kidney Diseases. Washington, DC, USA: U.S. Government Printing Office; 2007. p. 439-58.

19. Hansson S, Bollgren I, Esbjörner E, Jakobsson B, Mårild S. Urinary tract infections in children below two years of age: a quality assurance project in Sweden. The Swedish Pediatric Nephrology Association. Acta Paediatr 1999;88:270-4.

20. Stokland E, Hellström M, Jacobsson B, Jodal U, Sixt R. Evaluation of DMSA scintigraphy and urography in assessing both acute and permanent renal damage in children. Acta Radiol 1998;39:447-52.

21. Teppler H, Gesser RM, Friedland IR, Woods GL, Meibohm A, Herman G, et al. Safety and tolerability of ertapenem. Journal of Antimicrobial Chemotherapy 2004:53(Suppl 2);75-8.

22. Karaaslan A, Kadayifci EK, Atici S, Akkoc G, Yakut N, Öcal Demir $S$, et al. The clinical efficacy and safety of ertapenem for the treatment of complicated urinary tract infections caused by ESBL-producing bacteria in children. Int J Nephrol 2015;2015:595840.

\section{Çocuklarda Ertapenem Tedavisinin GSBL Üreten Mikroorganizmaların Sebep Olduğu İdrar Yolu Enfeksiyonlarında Etkinlik ve Güvenilirliği}

Amaç: Bu çalışmada idrar yolu enfeksiyonlarında (IYE) ertapenem tedavisinin klinik etkinlik ve güvenilirliğini araştırdık.

Gereç ve Yöntem: Geriye dönük olarak yapılan çalışmamıza Ağustos 2015 ve Haziran 2016 tarihleri arasında iYE nedeniyle ertapenem tedavisi alan yaşları 5 ila 153 ay arasında değişen 22 olgu dahil edildi.

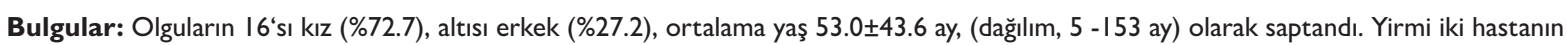
idrar kültüründe Escherichia coli $(n=2 I)$ ve Klebsiella pneumoniae $(n=I)$ saptandı. Olguların hepsinde tedavi süresi 10 güne tamamlandı. Tedavi sırasında olgularda herhangi bir yan etki görülmedi.

Sonuç: Çocuklarda GSBL üreten mikroorganizmaların neden olduğu iYE’larında ertapenem güvenli olarak kullanılabilmektedir.

Anahtar Sözcükler: Çocuk; ertapenem; GSBL; idrar yolu enfeksiyonu. 